\title{
Sensitivity and Specificity of Hepatitis B Virus Screening via Rapid Immunoassay Chromatographic Test
}

\author{
Rukhsana Saboor Soomro ${ }^{1}$, Iftikhar Ali Shah ${ }^{2}$, Abdul Saboor ${ }^{3}$, Aman Ullah B. Bhutto ${ }^{1}$, Sidra Memon ${ }^{4}$ \\ 1. Pathology, Ghulam Muhammad Mahar Medical College Hospital, Sukkur, PAK 2. Internal Medicine, Ghulam \\ Muhammad Mahar Medical College Hospital, Sukkur, PAK 3. Urology, Ghulam Muhammad Mahar Medical College \\ Hospital, Sukkur, PAK 4. Internal Medicine, Jinnah Sindh Medical University, Karachi, PAK
}

Corresponding author: Sidra Memon, sidramemon311@gmail.com

\begin{abstract}
Introduction: In low-income and high hepatitis B and C virus burden countries like Pakistan, it is important to develop cheap yet efficient strategies in diagnosing as well as treating hepatitis. The aim of this study is to assess the sensitivity and specificity of serum hepatitis B surface antigen ( $\mathrm{HbsAg}$ ) via Rapid Immunoassay Chromatographic Test (RICT) for the screening of hepatitis B, compared to the gold standard laboratorybased method.
\end{abstract}

Methods: The study was conducted in the Hepatology Clinic of Civil Hospital, Sukkur. All records of the clinic from June 1, 2018, to December 31, 2018, were accessed for identification of the records in which hepatitis B screening via RICT and then confirmatory polymerase chair reaction (PCR) by gene amplification with forward and reverse primers was done.

Results: There were 151 samples in this study. There were 32 (94.1\%) true-positive and three (5.8\%) falsenegative samples. There were two (2.5\%) false-positive and 114 (97.4\%) true-negative samples. The sensitivity of HbsAg detection via RICT for the screening of 1-1B V was $91.43 \%$, specificity was $98.28 \%$ and the accuracy was $96.69 \%$, compared to PCR.

Conclusion: The RICT method has high sensitivity and specificity. In low-income and high-hepatitis B virusburden countries like Pakistan, it serves as a very efficient screening tool that is easy to use, cheaper in cost, and gives rapid and accurate results.

Review began 01/10/2021 Review ended 01/19/2021 Published 01/25/2021

๑ Copyright 2021 Saboor Soomro et al. This is an open access article distributed under the terms of the Creative Commons Attribution License CC-BY 4.0., which permits unrestricted use, distribution, and reproduction in any medium, provided the original author and source are credited.

Categories: Internal Medicine, Gastroenterology

Keywords: hepatitis b, rict, serology

\section{Introduction}

Globally, around two billion people are infected with hepatitis B virus (HBV) [1]. Out of these, four hundred million are suffering from chronic HBV infection [2]. In Pakistan, as many as nine million people are infected with HBV [3,4]. This endemic situation in Pakistan has been explained by lack of proper healthcare facilities, poverty, and lack of awareness regarding its transmission [2].

Serological markers for hepatitis B include hepatitis B surface antigen (HbsAg), hepatitis B surface antibody (anti-HBs), hepatitis B e-antigen (HBeAg), hepatitis B e-antibody (anti-HBe), and hepatitis B core antibodies (anti-HBc IgM and IgG). These serological markers are used to identify patients with HBV infection, to predict the natural course of chronic hepatitis $\mathrm{B}(\mathrm{CHB})$, to note the clinical stages of hepatitis $\mathrm{B}$, and to monitor the efficacy of treatment given [5].

\begin{abstract}
Among these serological markers, HbsAg is considered as the hallmark of HBV infection. It takes one to 10 weeks for HbsAg to appear positive in blood after acute exposure to HBV, even before serum liver function tests becomes abnormal or the patient exhibits clinical symptoms of hepatitis. If HbsAg persists for more than six months, it indicates chronic infection [6]. After the resolution of hepatitis B, HbsAg becomes negative shortly after illness subsides. Hence, HbsAg plays a crucial role in screening healthy individuals for HBV with no clinical, laboratory, biochemical, or histological findings of chronic liver disease [7]. HbsAg can be detected using various techniques. One of them is rapid diagnostic tests (RDTs) in lateral flow, flowthrough or simple agglutination assays formats. Laboratory-based immunoassays to detect HBsAg include the conventional radioimmunoassay, enzyme immunoassays, and also newer technology such as electrochemiluminescence. [8]. In this study, the accuracy, sensitivity, and specificity of HBV screening by detecting HbsAg via Rapid Immunoassay Chromatographic Test (RICT) are evaluated as compared to the confirmatory polymerase chain reaction (PCR).
\end{abstract}

\section{Materials And Methods}




\section{Cureus}

The study was conducted in the Hepatology Clinic of Civil Hospital, Sukkur. All clinic records from June 1, 2018, to December 31, 2018, were accessed for identification of records in which hepatitis B screening via RICT (Determine; Abbott, Chicago, IL, USA) and then confirmatory PCR by gene amplification in forward and reverse primers (Macrogen, Seoul, Korea) was done. There were 151 such samples and all of these were included in the study. Those who were positive for HbsAg on screening were termed "screening positive" and the samples which were negative for HbsAg on screening were termed as "screening negative." PCR was done for all samples. Samples that were positive on screening and then also positive on PCR were termed as "true positive," those which were positive on screening but negative on PCR were termed as "false positive," samples which were negative on screening but were positive on PCR were termed as "false negative," and samples which were negative on both screening and PCR were termed as "true negative." Data were entered in Microsoft Excel and frequencies and percentages were calculated. A diagnostic test evaluation calculator on MedCalc (https://www.medcalc.org/) was used to determine sensitivity, specificity, accuracy, and positive and negative predictive value [9].

\section{Results}

There were 151 samples in this study. There were 34 (22.5\%) samples that were positive for HBV on screening and 117 (77.5\%) were negative. When a confirmatory test was done, there were 32 (94.1\%) true positive and three (5.8\%) false-negative samples. There were two (2.5\%) false-positive and $114(97.4 \%)$ true negative samples as shown in Table 1.

\begin{tabular}{|c|c|c|c|}
\hline \multicolumn{2}{|c|}{ Screening Positive ( $N=34)$} & \multicolumn{2}{|c|}{ Screening Negative $(\mathrm{N}=117)$} \\
\hline True-Positive & False-Positive & False-negative & True-negative \\
\hline $32(94.1 \%)$ & $2(5.8 \%)$ & $3(2.5 \%)$ & $114(97.4 \%)$ \\
\hline
\end{tabular}

\section{TABLE 1: Screening results}

$\mathrm{N}=$ number

The sensitivity of HbsAg detection via RICT for the screening of HBV was $91.43 \%$ in this study. The specificity was $98.28 \%$ and accuracy was $96.69 \%$ (Table 2).

\begin{tabular}{|c|c|c|}
\hline & Value & $95 \% \mathrm{Cl}$ \\
\hline Sensitivity & $91.43 \%$ & $76.94 \%$ to $98.20 \%$ \\
\hline Specificity & $98.28 \%$ & $93.91 \%$ to $99.79 \%$ \\
\hline Positive Predictive Value & $94.12 \%$ & $80.14 \%$ to $98.45 \%$ \\
\hline Negative Predictive Value & $97.44 \%$ & $92.79 \%$ to $99.12 \%$ \\
\hline Accuracy & $96.69 \%$ & $92.44 \%$ to $98.92 \%$ \\
\hline
\end{tabular}

TABLE 2: Sensitivity and Specificity Analysis

$\mathrm{Cl}=$ Confidence Interval

\section{Discussion}

For the longest time, HbsAg (hepatitis B surface antigen) has been used as the screening modality of hepatitis B virus and is considered of pivotal importance by World Health Organization (WHO) [10]. In countries with a low prevalence of $\mathrm{HBV}$, detection of anti-HBc (hepatitis B core antibody) has added to HbsAg as a screening modality. In countries with medium/high prevalence of HBV infection, besides HbsAg, tests for HBV deoxyribonucleic acid (DNA) have been implemented, usually together with equivalent tests for HCV ribonucleic acid (RNA) and HIV RNA [11].

In this study, HbsAg has shown high sensitivity, specificity, and accuracy for the hepatitis B virus. A metaanalysis of 33 studies [12] has shown pooled sensitivity and specificity of $90.0 \%$ (95\% CI: 89.1-90.8) and 99.5\% (95\% C1:99.4-99.5), respectively, which is comparable to the outcomes of this study. Comparatively, in a metanalysis from Korea, which is a high burden country in terms of HBV, the pooled sensitivity and 
specificity of serum HbsAg on RICT was 98.07\% (95\% CI:97.67-98.47\%) and 99.56\% (95\%CI:99.21-99.91\%), respectively [13].

Research has also associated positive serum HbsAg levels with transcription activity of covalently closed circular DNA (cccDNA) [14-16]. The difference in the serum HbsAg levels during the different phases of infection indicates the distribution of cccDNA during the respective phases of the disease. Serum HBsAg titers are higher in patients with HBeAg-positive chronic hepatitis B than those with HBeAg-negative chronic hepatitis [15-17]. Monitoring of quantitative HBsAg levels predicts treatment response to interferon and disease progression in HBeAg-negative chronic hepatitis B patients with normal serum alanine amine aminotransferase levels $[18,19]$.

RICT is easier to handle and cheaper in cost which is why almost all healthcare facilities use it in lieu of the gold standard enzyme-linked immunosorbent assay (ELISA). Although this study did not compare its RICT results with ELISA, which is one of its limitations, other studies from Pakistan have shown comparable results of both methods [20].

\section{Conclusions}

Overall, the RICT method has high sensitivity and specificity. In low-income and high-HBV-burden countries like Pakistan, it serves as a very efficient screening tool that is easy to use, cheaper in cost, and gives rapid and accurate results. It is recommended to conduct large scale studies to compare various brands of RICT and ELISA kits available in Pakistan to gauge their efficiency. Clinicians should eagerly use the RICT method for the detection of hepatitis B and C in their patients, as it provides a cheap and accurate alternative diagnosis for hepatitis $\mathrm{B}$.

\section{Additional Information \\ Disclosures}

Human subjects: Consent was obtained or waived by all participants in this study. Ghulam Muhammad Mahar Medical College, Sukkur issued approval GMMMC/ERC-Ofc/2018-18. Animal subjects: All authors have confirmed that this study did not involve animal subjects or tissue. Conflicts of interest: In compliance with the ICMJE uniform disclosure form, all authors declare the following: Payment/services info: All authors have declared that no financial support was received from any organization for the submitted work. Financial relationships: All authors have declared that they have no financial relationships at present or within the previous three years with any organizations that might have an interest in the submitted work. Other relationships: All authors have declared that there are no other relationships or activities that could appear to have influenced the submitted work.

\section{References}

1. Paraskevis D, Haida C, Tassopoulos N, et al.: Development and assessment of a novel real-time PCR assay for quantitation of HBV DNA. J Virol Methods. 2002, 103:201-212. 10.1016/s0166-0934(02)00033-2

2. Alam MM, Zaidi SZ, Malik SA, et al.: Serology based disease status of Pakistani population infected with Hepatitis B virus. BMC Infect Dis. 2007, 7:64. 10.1186/1471-2334-7-64

3. Noorali S, Hakim ST, McLean D, et al.: Prevalence of Hepatitis B virus genotype D in females in Karachi, Pakistan. J Infect Dev Ctries. 2008, 2:373-378. 10.3855/jidc.200

4. Hakim ST, Kazmi SU, Bagasra O: Seroprevalence of hepatitis B and C genotypes among young apparently healthy females of Karachi Pakistan. Libyan J Med. 2008, 3:66-70. 10.4176/071123

5. Centers for Disease Control and Prevention: Epidemiology and Prevention of Vaccine-Preventable Diseases. Hamborsky J, Kroger A, Wolfe S (ed): Washington DC: Public Health Foundation, Washington DC; 2011.

6. Kao JH: Diagnosis of hepatitis B virus infection through serological and virological markers . Expert Rev Gastroenterol Hepatol. 2008, 2:553-562. 10.1586/17474124.2.4.553

7. Larke RP: The HbsAg-positive positive patient: implications and a guide to management . Can Fam Physician. 1979, 25:317-319.

8. Amini A, Varsaneux O, Kelly H, et al.: Diagnostic accuracy of tests to detect hepatitis B surface antigen: a systematic review of the literature and meta-analysis. BMC Infect Dis. 2017, 17:698. 10.1186/s12879-0172772-3

9. MedCalc's Diagnostic test evaluation calculator. (2019). Accessed: March 19, 2019: https://www.medcalc.org/calc/diagnostic_test.php.

10. Screening Donated Blood for Transfusion-Transmissible Infections: Recommendations. (2010). Accessed: October 1, 2011: http://www.who.int/entity/bloodsafety/en/.

11. Velati C, Fomiatti L, Baruffi L, et al.: Criteria for hepatitis B virus screening and validation of blood components in Italy: the position of the SIMTI HBV working group. Blood Transfus. 2011, 9:455-61. 10.2450/2011.0014-11

12. Amini A, Varsaneux O, Kelly H, et al.: Diagnostic accuracy of tests to detect hepatitis B surface antigen: a systematic review of the literature and meta-analysis. BMC Infect Dis. 2017, 17:698. 10.1186/s12879-0172772-3

13. Hwang SH, Oh HB, Choi SE, Kim HH, Chang CL, Lee EY, Son HC: Meta-analysis for the pooled sensitivity and specificity of hepatitis B surface antigen rapid tests. Korean J Lab Med. 2008, 28:160-168. 10.3343/kjlm.2008.28.2.160

14. Chan HL, Wong VW, Tse AM, et al.: Serum hepatitis B surface antigen quantitation can reflect hepatitis B 


\section{Cureus}

virus in the liver and predict treatment response. Clin Gastroenterol Hepatol. 2007, 5:1462-1468. 10.1016/j.cgh.2007.09.005

15. Nguyen T, Thompson Aj, Bowden S, et al.: Hepatitis B Surface antigen levels during the natural history of chronic hepatitis B: a perspective on Asia. J Hepatol. 2010, 52:508-513. 10.1016/j.jhep.2010.01.007

16. Thompson AJ, Nguyen T, Iser D, et al.: Serum hepatitis B surface antigen and hepatitis B e antigen titers: disease phase influences correlation with viral load and intrahepatic hepatitis B virus markers. Hepatol. 2010, 51:1933-1944. 10.1002/hep.23571

17. Jaroszewicz j, Calle Serrano B, Wursthorn K, et al.: Hepatitis B Surface antigen (HbsAg) levels in the natural history of hepatitis B virus (HBV)-infection: a European perspective. J Hepatol. 2010, 52:514-522. 10.1016/j.jhep.2010.01.014

18. Chan HL, Thompson A, Martinot-Peignoux M, et al.: Hepatitis B surface antigen quantification: why and how to use it in 2011 - a core group report. J Hepatol. 2011, 55:1121-1131. 10.1016/j.jhep.2011.06.006

19. Martinot-Peignoux M, Carvalho-Filho R, Lapalus M, et al.: Hepatitis B surface antigen serum level is associated with fibrosis severity in treatment-naïve.e antigen-positive patients. J Hepatol. 2013, 58:10891095. 10.1016/j.jhep.2013.01.028

20. Qasmi SA, Aqeel S, Ahmed M, et al.: Detection of hepatitis B viruses in normal individuals of Karachi . J Coll Physicians Surg Pak. 2000, 10:467-9. 